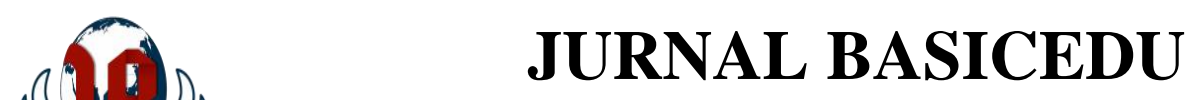

Volume 5 Nomor 4 Tahun 2021 Halaman 2189 - 2198

Research \& Learning in Elementary Education

https://jbasic.org/index.php/basicedu

\title{
Penerapan Model Pembelajaran Explicit Instruction untuk Meningkatkan Hasil Belajar Siswa Sekolah Dasar
}

\author{
Suratih Melianni Sibagariang ${ }^{1 凶}$, Asnita Hasibuan², Patri Janson Silaban ${ }^{3}$ \\ Pendidikan Guru Sekolah Dasar, Universitas Katolik Santo Tomas Medan, Indonesia ${ }^{1,2,3}$ \\ E-mail: suratihmeliani@gmail.com ${ }^{1}$, asnita103hasibuan@gmail.com² ${ }^{2}$, patri_silaban280388@yahoo.co.id ${ }^{3}$
}

\begin{abstract}
Abstrak
Penelitian ini bertujuan untuk mengetahui peningkatan hasil belajar siswa dengan menerapkan model Explicit Instruction pada tema Udara Bersih Bagi Kesehatan di kelas V SD Negeri 106144 Sei Mencirim. Penelitian ini merupakan penelitian tindakan kelas yang dilaksanakan dalam dua siklus. Subjeknya yaitu peserta didik kelas V SD Negeri 106144 Sei Mencirim yang berjumlah 22 siswa yaitu 9 laki-laki dan 13 perempuan. Teknik pengumpulan data yang digunakan adalah tes, dokumentasi, dan observasi. Hasil penelitian menunjukkan adanya peningkatan hasil belajar siswa. Pada pretest (tes awal) siswa yang tuntas $27 \%$ dan tidak tuntas $73 \%$, dengan nilai rata-rata 56. Pada post-test siklus I meningkat menjadi $64 \%$ yang tuntas, sedangkan yang tidak tuntas $36 \%$, dengan nilai rata-rata 70 . Pada post-test siklus II meningkat menjadi $82 \%$ yang tuntas, sedangkan yang tidak tuntas $18 \%$, dengan nilai rata-rata 81 . Selanjutnya, skor dari hasil observasi kegiatan guru pada siklus I dan meningkat pada siklus II yaitu nilai 78 (baik) meningkat menjadi nilai 85 (sangat baik) dan skor observasi kegiatan siswa pada siklus I dengan nilai 65 (cukup) meningkat pada siklus II dengan nilai 84 (baik).
\end{abstract}

Kata Kunci : Hasil Belajar, Model Explicit Instruction.

\begin{abstract}
This study aims to determine the improvement of student learning outcomes by applying the Explicit Instruction model on the theme of Clean Air for Health in class V SD Negeri 106144 Sei Mencirim. This research is a classroom action research conducted in two cycles. The subjects were the fifth grade students of SD Negeri 106144 Sei Mencirim, totaling 22 students, namely 9 boys and 13 girls. The data collection techniques used were tests, documentation, and observations. The results showed an increase in student learning outcomes. In the pretest (initial test) students who completed $27 \%$ and did not complete $73 \%$, with an average score of 56. In the post-test cycle I increased to 64\% who completed, while those who did not complete $36 \%$, with an average score of 70 In the post-test cycle II it increased to $82 \%$ complete, while $18 \%$ incomplete, with an average value of 81 . Furthermore, the score from the observation of teacher activities in cycle I and increased in cycle II was 78 (good). increased to a value of 85 (very good) and the score of student activity observation in the first cycle with a value of 65 (sufficient) increased in the second cycle with a value of 84 (good).
\end{abstract}

Keywords: Learning Outcomes, Explicit Instruction Model.

Copyright (c) 2021 Suratih Melianni Sibagariang, Asnita Hasibuan, Patri Janson Silaban

Corresponding author :

Email : suratihmeliani@gmail.com

DOI : https://doi.org/10.31004/basicedu.v5i4.586

ISSN 2580-3735 (Media Cetak)

ISSN 2580-1147 (Media Online)

Jurnal Basicedu Vol 5 No 4 Tahun 2021

p-ISSN 2580-3735 e-ISSN 2580-1147 
2190 Penerapan Model Pembelajaran Explicit Instruction untuk Meningkatkan Hasil Belajar Siswa Sekolah Dasar - Suratih Melianni Sibagariang, Asnita Hasibuan, Patri Janson Silaban

DOI: https://doi.org/10.31004/basicedu.v5i4.586

\section{PENDAHULUAN}

Pendidikan sebagai suatu pondasi yang membantu memahami segala sesuatu dalam kehidupan, bagi setiap orang tentunya sangat penting. Pendidikan merupakan upaya agar manusia mampu meningkatkan pengetahuan, keterampilan serta kepribadian dirinya melalui proses pembelajaran dan atau cara lain yang diakui dan dikenal oleh masyarakat dari lingkungannya, dengan harapan sesuatu yang ingin ditingkatkan adalah layak untuk diketahui, dikembangkan, dan diajarkan. Belajar tidak hanya memahami sifat "benar" dari segala sesuatu, melainkan untuk membangun pengalaman yang bermakna bagi pribadi orang yang belajar.

Dalam pembelajaran pada pendidikan formal (sekolah) masalah utamanya adalah masih rendahnya daya serap siswa yang menyebabkan nilai rata-rata yang diperoleh peserta didik tersebut rendah. Penyebab rendahnya kemampuan peserta didik dalam memahami materi dikarenakan kurang efektifnya pembelajaran yang diciptakan guru.

Ketidakefektifan itu disebabkan kurang tepatnya model pembelajaran yang diterapkan guru di kelas. Model pembelajaran yang dipakai guru tidak dapat mengajak peserta didik untuk terlibat secara aktif di kelas. Hal tersebut sesuai dengan pendapat (Huda, 2014) mengemukakan; kurangnya aktivitas fisik dan mental dapat menyebabkan lemahnya kapasitas otak. Selanjutnya, otak aktif akan berfungsi lebih baik daripada otak yang tidak dilibatkan dalam menciptakan aktivitas-aktivitas fisik dan/atau latihan-latihan mental, jadi pembelajaran bisa berlangsung dengan baik ketika seseorang bisa terlibat dalam proses tersebut.

Berikut adalah tabel hasil Ujian Formatif siswa tahun pembelajaran 2019/2020:

\section{Tabel 1. Nilai Hasil Ujian Formatif Siswa Kelas V SD Negeri 106144 Sei Mencirim Tema Udara Bersih Bagi Kesehatan Tahun Pembelajaran 2019/2020}

\begin{tabular}{cccc}
\hline \multirow{2}{*}{ KKM } & $\begin{array}{c}\text { Jumlah } \\
\text { Siswa }\end{array}$ & \multicolumn{2}{c}{ Jumlah Siswa } \\
\cline { 3 - 4 } 72 & 23 & $\begin{array}{c}8 \\
\text { Tuntas }\end{array}$ & $\begin{array}{c}\text { Tidak } \\
\text { Tuntas }\end{array}$ \\
\hline
\end{tabular}

Untuk memperbaiki hasil belajar dan meningkatkan minat belajar siswa salah satu solusi yang dapat dilakukan guru sebagai tenaga pengajar dalam mengembangkan pembelajaran tema Udara Bersih bagi Kesehatan, yaitu dengan penerapan model pembelajaran yang tepat dan mampu menumbuhkan rasa ingin tahu, aktif, suasana menyenangkan, kondusif, dan mengembangkan kreatifitas siswa. Dengan penerapan model pembelajaran yang tepat tersebut dan mengaitkan materinya dengan kehidupan nyata dengan lingkungan sekitar siswa, akan dengan mudah menarik pemahaman dan minat siswa pada materi tersebut dalam proses pembelajaran.

Adapun model yang mampu melibatkan keaktifan dan kreatifitas siswa adalah model Explicit Instruction. Model pembelajaran Explicit Instruction menempatkan guru sebagai fasilitator yakni menyelenggarakan berlangsungnya pembelajaran mulai dari perencanaan, pelaksanaan terutama pemberian pertanyaan arahan dan pemberian bimbingan sampai evaluasi. Secara umum, "Model ini sering dikenal dengan pengajaran langsung" (Huda, 2014). Hal ini akan menigkatkan kepercayaan diri siswa untuk menanyakan tentang hal yang belum mereka pahami sebelumnya.

Tujuan yang hendak dicapai dalam penelitian ini adalah: (1) Untuk mengetahui bagaimana perkembangan proses pelaksanaan pembelajaran dengan diterapkannya model pembelajaran Explicit Instruction, (2) Untuk mengetahui model pembelajaran Explicit Instruction dapat meningkatkan hasil belajar siswa. Kita belajar untuk membangun pengetahuan diri kita. Banyak pengetahuan dan informasi "di luar sana" yang dapat menambah wawasan kita lebih luas. Dalam proses belajar tentu saja memerlukan waktu. Karena 
2191 Penerapan Model Pembelajaran Explicit Instruction untuk Meningkatkan Hasil Belajar Siswa Sekolah Dasar - Suratih Melianni Sibagariang, Asnita Hasibuan, Patri Janson Silaban

DOI: https://doi.org/10.31004/basicedu.v5i4.586

sejatinya belajar dapat dilakukan dimana saja tanpa mengenal waktu dan ruang. Sesuai dengan pendapat (Sumiati \& Asra, 2018) mengatakan bahwa, "Belajar itu suatu proses, tentu membutuhkan waktu. Hasil belajar tidak terjadi secara tiba-tiba, tetapi memerlukan usaha. Sedangkan, usaha itu juga memerlukan waktu, cara, dan metode pembelajaran".

Salah satu prinsip terpenting juga dalam belajar ialah memahami tujuan dan apa manfaat yang diperoleh, agar tiap siswa yang belajar tidak secara terpaksa dan kebingungan untuk melaksanakannya. Sehingga siswa memperoleh pembelajaran yang bermakna yang membangun pengetahuannya. Dan (Anderson \& Krthwohl, 2010) mengenai belajar bermakna mengemukakan, "Pembelajaran konstruktif (yakni belajar yang bermakna) dipandang sebagai tujuan pendidikan yang penting. Pembelajaran konstruktif mensyaratkan pembelajaran yang tidak sekedar menyampaikan pengetahuan faktual dan juga mensyaratkan pertanyaanpertanyaan asesmen yang menuntut siswa bukan sekedar mengingat atau mengenali pengetahuan faktual".

Dalam dunia pendidikan model pembelajaran merupakan suatu cara yang dirancang dan digunakan guru dalam proses pembelajaran yang mendekatkan siswa dengan materi yang akan disampaikan guru.

Model pembelajaran Explicit Instruction sering juga disebut model pengajaran langsung. Sesuai dengan menurut (Trianto, 2012) mengatakan bahwa, "Istilah model pengajaran langsung sering disebut juga dengan model pengajaran aktif (active teaching model), training model, mastery teaching, dan explicit instruction".

Menurut (Huda, 2014) mengatakan bahwa, "Explicit Instruction dapat berbentuk ceramah, demonstrasi, pelatihan atau praktik, dan kerja kelompok. Strategi ini juga dapat digunakan untuk menyampaikan pelajaran yang ditransformasikan langsung oleh guru kepada siswa".

Agar pelaksanaan pembelajaran dengan menggunakan model Explicit Instruction dapat berlangsung secara efektif maka guru perlu mempersiapkan langkah-langkah pembelajaran. Menurut Kardi dan Nur (Trianto, 2012) mengatakan bahwa Sintaks (Tahapan) model Pembelajaran Explicit Instruction disajikan dalam lima tahap yaitu :

Tabel 2. Sintaks Model Pembelajaran Explicit Instruction

\begin{tabular}{cl}
\hline Fase & \multicolumn{1}{c}{ Peran Guru } \\
\hline $\begin{array}{c}\text { Fase 1 } \\
\text { Menyampaikan tujuan dan } \\
\text { mempersiapkan siswa }\end{array}$ & $\begin{array}{l}\text { Guru menjelaskan TPK informasi latar } \\
\text { belakang pelajaran, pentingnya pelajaran, } \\
\text { mempersiapkan siswa untuk belajar. }\end{array}$ \\
\hline $\begin{array}{c}\text { Fase 2 } \\
\text { Mendemonstrasikan pengetahuan dan } \\
\text { keterampilan }\end{array}$ & $\begin{array}{l}\text { Guru memdemonstrasikan keterampilan } \\
\text { dengan benar, atau menyajikan informasi } \\
\text { tahap demi tahap. }\end{array}$ \\
\hline $\begin{array}{c}\text { Fase 3 } \\
\text { Membimbing pelatihan }\end{array}$ & $\begin{array}{l}\text { Guru merencanakan dan memberi bimbingan } \\
\text { pelatihan awal. }\end{array}$ \\
\hline Fase 4 & $\begin{array}{l}\text { Mencek apakah siswa telah berhasil } \\
\text { melakukan tugas dengan baik, memberi } \\
\text { umpan balik. }\end{array}$ \\
\hline $\begin{array}{c}\text { Mengecek Pemahaman dan memberikan } \\
\text { umpan balik }\end{array}$ & $\begin{array}{l}\text { Guru mempersiapkan kesempatan melakukan } \\
\text { pelatihan lanjutan, dengan perhatihan khusus } \\
\text { pada penerapan kepada situasi lebih } \\
\text { kempleks dan kehidupan sehari-hari. }\end{array}$ \\
\hline $\begin{array}{c}\text { Memberikan kesempatan untuk pelatihan } \\
\text { lanjutan dan penerapan }\end{array}$ &
\end{tabular}

Manfaat teoritis penelitian ini dapat menambah referensi di bidang pendidikan, terutama dalam meningkatkan hasil belajar pada siswa kelas $\mathrm{V}$ sekolah dasar. Melalui penggunaan model pembelajaran Explicit Intruction siswa dituntut untuk berperan aktif dan memberi diri sehingga tujuan pembelajaran yang hendak dicapai dapat tercapai dengan baik. Kondisi akhir yang diharapkan adalah adanya peningkatan keterampilan guru dalam mengajar dan meningkatkan hasil belajar siswa dalam Tema 2 Udara Bersih bagi 
2192 Penerapan Model Pembelajaran Explicit Instruction untuk Meningkatkan Hasil Belajar Siswa Sekolah Dasar - Suratih Melianni Sibagariang, Asnita Hasibuan, Patri Janson Silaban

DOI: https://doi.org/10.31004/basicedu.v5i4.586

Kesehatan, Subtema 3 Memelihara Kesehatan Organ Pernapasan Manusia, Pembelajaran 2 di Kelas V SD Negeri 106144 Sei Mencirim Tahun Pembelajaran 2020/2021.

\section{METODE PENELITIAN}

Penelitian ini dilakukan dengan menggunakan pendekatan campuran melalui metode Penelitian Tindakan Kelas (PTK). Pendekatan campuran itu sendiri merupakan gabungan dari pendekatan kualitatif dan pendekatan kuantitatif. Metode ini adalah cara yang digunakan untuk mengumpulkan data penelitian. Sesuai dengan jenis penelitian ini, maka penelitian memiliki tahap-tahap berupa siklus prosedur penelitian yang terdiri dari dua siklus. Tiap siklus dilaksanakan sesuai dengan perubahan yang akan dicapai.

Menurut (Arikunto, Suhardjono, \& Supardi, 2017) mengatakan bahwa, "Penelitian Tindakan Kelas adalah penelitian yang memaparkan terjadinya sebab-akibat dari perlakuan, sekaligus memaparkan apa saja yang terjadi ketika perlakuan diberikan, dan memaparkan seluruh proses sejak awal pemberian perlakuan sampai dengan dampak dari perlakuan tersebut". Pelaksanaan penelitian ini dilakukan dengan 2 siklus, setiap siklus terdiri dari empat komponen yaitu: perencanaan, pelaksanaan, observasi dan refleksi. Dimana siklus I digunakan sebagai acuan dan menentukan perbaikan tindakan pada siklus II, sedangkan siklus II nantinya digunakan sebagai acuan untuk rencana tindak lanjut pembelajaran berikutnya.

Dalam penelitian ini proses pengumpulan datanya melalui beberapa cara yaitu dengan melakukan observasi/pengamatan, dokumentasi, dan tes. Informannya dalam penelitian ini adalah guru SD Negeri 106144 Sei Mencirim.

Analisis data merupakan tahap pengelolaan data hasil penelitian pada setiap siklus yang dalam proses penelitian untuk mendeskripsikan hasil penelitian dan mengetahui perubahan hasil belajar siswa yang diperoleh melalui hasil observasi dengan menggunakan model Explicit Instruction. Perhitungan uji validitas ini menggunakan bantuan Statistical Package for the Social Sciences (SPSS) dan Microsoft Office Excel. Cara yang digunakan untuk mengetahui tingkat validitas instrumen pada penelitian ini adalah menggunakan rumus korelasi product moment (Jihad, Asep, \& Harris, 2018). Setelah instrument soal divaliditas, maka dilakukan kembali dengan reliabilitas soal. (Jihad, Asep, \& Harris, 2018) berpendapat, "Reliabilitas soal merupakan ukuran yang menyatakan tingkat keajengan atau kekonsistenan suatu soal tes". Untuk menguji reliabilitas tes, maka digunakan rumus KR-20.

Indikator kerja yang ingin diperoleh dalam penelitian tindakan kelas ini adalah meningkatnya hasil belajar siswa setelah menerapkan model pembelajaran Explicit Instruction, sebagai ukuran keberhasilan pelaksanaan penelitian tindakan kelas ini ialah: (1) Indikator keberhasilan kualitas pelaksanaan pembelajaran aktivitas guru dan siswa minimal baik dan (2) Indikator keberhasilan hasil belajar secara klasikal minimal mencapai $75 \%$ dari jumlah siswa yang mencapai KKM yang ditetapkan yaitu 72 .

Jika hasil belum memuaskan akan dilakukan siklus 2, begitu seterusnya. Siklus akan berhenti jika hasil belajar siswa sudah memenuhi ukuran keberhasilan pelaksanaan pembelajaran penelitian tindakan kelas ini.

Penelitian ini dilakukan di SD Negeri 106144 Sei Mencirim Jln. Pasar I Sei Mencirim Kecamatan Sunggal, Kabupaten Deli Serdang. Subjek dalam penelitian ini adalah siswa kelas V SD yang berjumlah 22 siswa yang terdiri dari 9 orang laki-laki dan 13 orang perempuan pada semester I SD Negeri 106144 Sei Mencirim tahun pembelajaran 2020/2021.

\section{HASIL DAN PEMBAHASAN}

Penelitian ini dilaksanakan sebanyak dua siklus yang meliputi perencanaan, pelaksanaan, observasi, dan refleksi. Dalam pelaksanaan penelitian ini, peneliti dan guru kelas melakukan kerjasama, dimana peneliti bertindak sebagai guru dan guru kelas bertugas sebagai untuk mengamati kegiatan guru dalam proses belajar 
2193 Penerapan Model Pembelajaran Explicit Instruction untuk Meningkatkan Hasil Belajar Siswa Sekolah Dasar - Suratih Melianni Sibagariang, Asnita Hasibuan, Patri Janson Silaban

DOI: https://doi.org/10.31004/basicedu.v5i4.586

mengajar. Penelitian ini dilaksanakan dengan menggunakan model pembelajaran Explicit Instruction yang bertujuan untuk mengetahui peningkatan hasil belajar siswa kelas V SD Negeri 106144 Sei Mencirim pada tema Udara Bersih Bagi Kesehatan, subtema 3 Memelihara Kesehatan Organ Pernapasan Manusia Pembelajaran 2 dan 5.

Langkah awal yang dilakukan peneliti sebelum melaksanakan penelitian tindakan kelas, yaitu melakukan pengamatan awal berupa kegiatan prasiklus untuk mengetahui keadaan awal tentang hasil belajar siswa. Berdasarkan pengamatan awal dan hasil tes, menunjukkan nilai rata-rata masih tergolong rendah atau masih di bawah nilai KKM (72). Pelaksanaan pembelajaran juga belum maksimal, karena saat guru menjelaskan materi pembelajaran masih ada siswa yang ribut, siswa yang mengantuk Hal lain dikarenakan guru kurang menggunakan media pembelajaran sehingga siswa tidak aktif dan kreatif. Metode yang digunakan guru juga kurang bervariasi sehingga pembelajaran kurang menarik bagi siswa. Sehingga pembelajaran berlangsung secara monoton dan membuat siswa merasa bosan dan kurang memperhatikan pelajaran yang sedang disampaikan. Adapun nilai hasil belajar yang diperoleh siswa setelah diberikan pretest pada prasiklus dan post-test pada siklus I dan siklus II.

Berdasarkan data yang diperoleh dari observasi aktivitas guru pada siklus I dan siklus II dapat dilihat adanya peningkatan. Dimana pada siklus I hasil observasi aktivitas guru diperoleh sebesar $78 \%$ dengan kategori B yang bermakna baik dan pada siklus II meningkat menjadi 85\% dengan kategori A yang bermakna sangat baik. Berdasarkan peningkatan kedua siklus ini dapat dilihat bahwa dari siklus I ke siklus II terdapat peningkatan sebesar $7 \%$.

Dan berdasarkan data yang diperoleh dari observasi aktivitas siswa pada siklus I dan siklus II dapat dilihat adanya peningkatan. Dimana pada siklus I hasil observasi aktivitas siswa diperoleh nilai sebesar 65 dengan kategori cukup dan pada siklus II meningkat menjadi 84 dengan kategori baik. Berdasarkan peningkatan kedua siklus ini dapat dilihat bahwa dari siklus I ke siklus II terdapat peningkatan nilai. Untuk lebih jelas mengenai peningkatan hasil dari observasi aktivitas guru dapat dilihat pada gambar diagram di bawah ini:

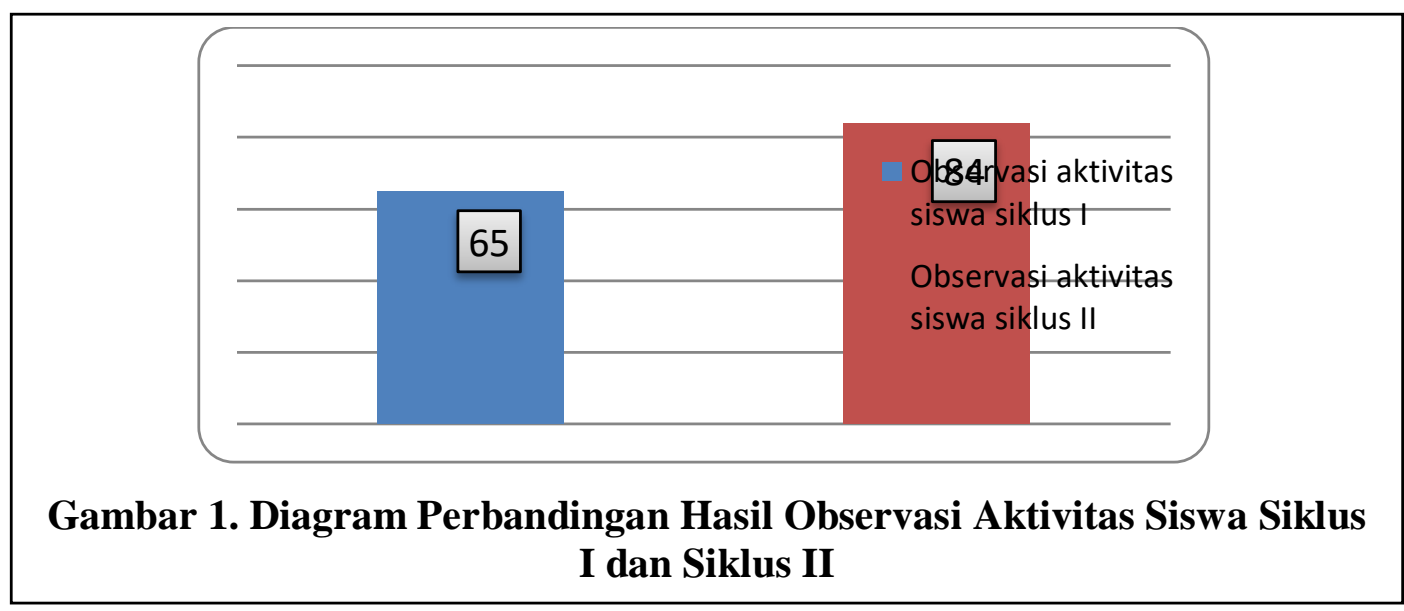

Berdasarkan data yang diperoleh dari rata-rata hasil belajar pada post-test siklus I dan siklus II dapat dilihat adanya peningkatan. Pada post-test siklus I rata-rata hasil diperoleh sebesar 70 sedangkan pada post test siklus II rata-rata hasil belajar meningkat menjadi 81. Berdasarkan peningkatan yang diperoleh dari data hasil belajar siswa maka dapat dilihat bahwa dari post test siklus I ke post-test siklus II mengalami peningkatan sebesar 11. Untuk lebih jelas mengenai peningkatan rata-rata hasil belajar siswa dapat dilihat pada gambar diagram di bawah ini: 
2194 Penerapan Model Pembelajaran Explicit Instruction untuk Meningkatkan Hasil Belajar Siswa Sekolah Dasar - Suratih Melianni Sibagariang, Asnita Hasibuan, Patri Janson Silaban

DOI: https://doi.org/10.31004/basicedu.v5i4.586

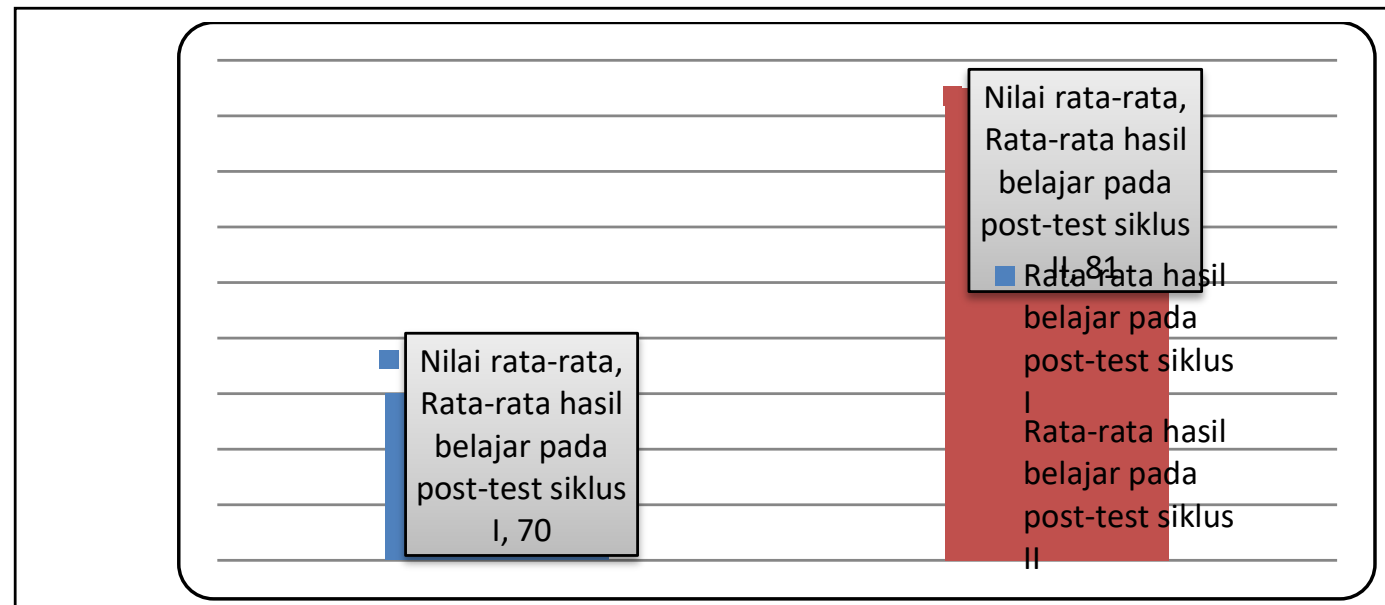

Gambar 2. Diagram Perbandingan Rata- rata Hasil Belajar Siswa pada Post-test Siklus I dan Siklus II

Peningkatan hasil belajar siswa antar siklus dapat dilihat pada tabel di bawah ini:

Tabel 3. Ketuntasan Hasil Belajar Siswa Secara Individual antar-Siklus

\begin{tabular}{|c|c|c|c|c|}
\hline \multirow{2}{*}{$\begin{array}{l}\text { No. } \\
\text { Urut }\end{array}$} & \multirow{2}{*}{$\begin{array}{l}\text { Nama } \\
\text { Siswa }\end{array}$} & \multirow{2}{*}{$\begin{array}{l}\text { Pre } \\
\text { test }\end{array}$} & \multicolumn{2}{|c|}{ Post-test } \\
\hline & & & $\begin{array}{c}\text { Siklus } \\
\text { I }\end{array}$ & Siklus II \\
\hline 1 & ALB & 73 & 80 & 93 \\
\hline 2 & ANJ & 70 & 80 & 80 \\
\hline 3 & ANJ & 33 & 53 & 60 \\
\hline 4 & $\mathrm{AT}$ & 80 & 80 & 87 \\
\hline 5 & ANS & 20 & 47 & 73 \\
\hline 6 & DT & 50 & 73 & 80 \\
\hline 7 & DP & 73 & 80 & 93 \\
\hline 8 & FR & 60 & 87 & 80 \\
\hline 9 & FA & 53 & 73 & 93 \\
\hline 10 & IR & 40 & 40 & 60 \\
\hline 11 & MR & 67 & 73 & 80 \\
\hline 12 & NMP & 40 & 60 & 67 \\
\hline 13 & NA & 80 & 93 & 87 \\
\hline 14 & $\mathrm{NH}$ & 77 & 80 & 80 \\
\hline 15 & OR & 30 & 60 & 80 \\
\hline 16 & $\mathrm{RS}$ & 50 & 67 & 87 \\
\hline 17 & $\mathrm{RN}$ & 43 & 60 & 67 \\
\hline 18 & SA & 67 & 80 & 80 \\
\hline 19 & SNR & 53 & 73 & 93 \\
\hline 20 & US & 30 & 47 & 80 \\
\hline 21 & WI & 87 & 87 & 87 \\
\hline 22 & YKS & 50 & 73 & 87 \\
\hline \multicolumn{2}{|c|}{ Jumlah } & 1226 & 1546 & 1774 \\
\hline \multicolumn{2}{|c|}{ Nilai Rata-rata } & 56 & 70 & 81 \\
\hline
\end{tabular}


2195 Penerapan Model Pembelajaran Explicit Instruction untuk Meningkatkan Hasil Belajar Siswa Sekolah Dasar - Suratih Melianni Sibagariang, Asnita Hasibuan, Patri Janson Silaban

DOI: https://doi.org/10.31004/basicedu.v5i4.586

Dari tabel 3. di atas dapat dilihat bahwa siswa yang tuntas hasil belajarnya pada pretest terdapat 6 orang siswa (27\%) dan siswa yang tidak tuntas 16 orang siswa (73\%). Pada post test siklus I yang tuntas terdapat 14 orang siswa (64\%) dan siswa yang tidak tuntas 8 orang siswa (36\%). Pada post test siklus II, diperoleh hasil belajar siswa dari 22 orang jumlah siswa terdapat 18 orang siswa yang tuntas hasil belajarnya (82\%), sedangkan yang tidak tuntas hasil belajarnya sebanyak 4 orang siswa (18\%). Dengan demikian penggunaan model pembelajaran Explicit Intruction dapat meningkatkan hasil belajar siswa pada Tema Udara Bersih Bagi Kesehatan.

Setelah dirangkum hasil ketuntasan belajar siswa secara individual, maka selanjutnya dari data tabel 3 diperoleh hasil belajar siswa secara klasikal dalam tabel 4. berikut ini:

Tabel 4. Ketuntasan Hasil Belajar Siswa Secara Klasikal antar-Siklus

\begin{tabular}{clc}
\hline No & Jenis Tes & $\begin{array}{c}\text { Persentase } \\
\text { Ketuntasan } \\
\text { Klasikal }\end{array}$ \\
\hline 1 & Pretest & $27 \%$ \\
\hline 2 & Post-test siklus I & $64 \%$ \\
\hline 2 & Post-test siklus II & $82 \%$ \\
\hline
\end{tabular}

Hasil dari Tabel 4. menunjukkan bahwa nilai siswa mengalami peningkatan dari dilaksanakannya pretest dan post-test tiap siklus dapat dilihat pada gambar diagram di bawah ini:

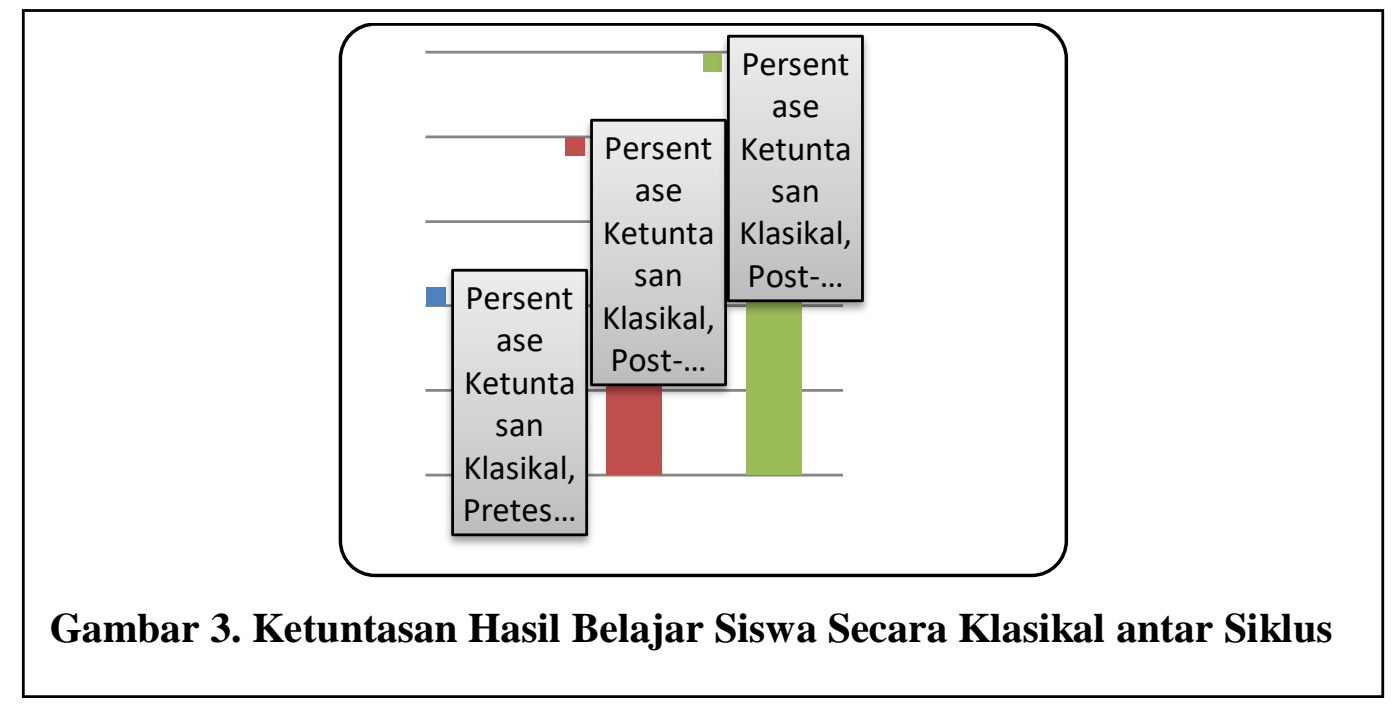

Untuk mengetahui berhasil tidaknya tindakan yang dilakukan dalam penelitian sesuai dengan tujuan penelitian, maka dicari juga nilai rata-rata di dalam kelas pada pretest, post-test siklus I, dan post-test siklus II pada tabel dibawah ini:

Tabel 5. Ketuntasan Rata-rata Hasil Belajar Siswa antar-Siklus

\begin{tabular}{|c|l|c|}
\hline No & Jenis Tes & $\begin{array}{c}\text { Rata-rata } \\
\text { Hasil } \\
\text { Belajar }\end{array}$ \\
\hline 1 & Pretest & 56 \\
\hline 2 & $\begin{array}{l}\text { Post-test } \\
\text { siklus I }\end{array}$ & 70 \\
\hline 3 & $\begin{array}{l}\text { Post-test } \\
\text { siklus II }\end{array}$ & 81 \\
\hline
\end{tabular}


Dari Tabel 5. menunjukkan terjadi peningkatan nilai rata-rata dimana pada pretest rata-rata hasil belajar sebesar 56, pada post-test siklus I rata-rata hasil belajar sebesar 70, dan pada post-test siklus II rata-rata hasil belajar sebesar 81. Untuk lebih jelas dapat dilihat dari gambar diagram di bawah ini:

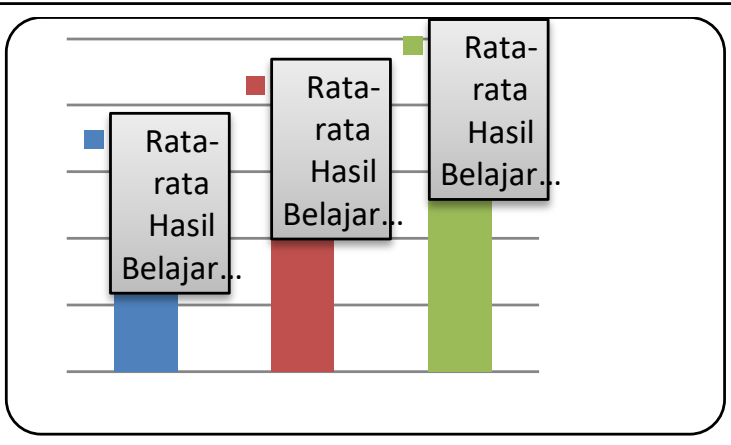

Gambar 4. Ketuntasan Rata-rata Hasil Belajar Siswa antar Siklus

Dari pembahasan data yang telah diperoleh peneliti dapat dilihat bahwa terdapat peningkatan hasil belajar yang baik dari siklus I dan siklus II. Penelitian ini dikatakan berhasil apabila ketuntasan hasil belajar siswa secara klasikal mencapai $75 \%$ dan pada siklus II diperoleh ketuntasan hasil belajar secara klasikal sebesar $82 \%$ jadi dapat disimpulkan bahwa melalui temuan yang telah diperoleh peneliti dapat memberikan jawaban terhadap hipotesis tindakan yang telah dikemukakan sebelumnya bahwa dengan penerapan model pembelajaran Explicit Intruction terjadi peningkatan terhadap hasil belajar siswa pada Tema Udara Bersih Bagi Kesehatan di kelas V SD Negeri 106144 Sei Mencirim.

\section{KESIMPULAN}

Berdasarkan hasil penelitian dan pembahasan mengenai peningkatan hasil belajar siswa dengan menerapkan model pembelajaran Explicit Intruction terjadi peningkatan terhadap hasil belajar siswa pada Tema Udara Bersih Bagi Kesehatan, Subtema 3 Memelihara Kesehatan Organ Pernapasan Manusia, pembelajaran 2 dan 5 di kelas V SD Negeri 106144 Sei Mencirim, dapat disimpulkan bahwa:

(1) Penerapan model pembelajaran Explicit Intruction dapat meningkatkan keterampilan guru pada Tema Udara Bersih Bagi Kesehatan, Subtema 3 Memelihara Kesehatan Organ Pernapasan Manusia, pembelajaran 2 dan 5 di kelas V SD Negeri 106144 Sei Mencirim. Hal ini dapat dilihat dari hasil observasi keterampilan guru selama penelitian yang menunjukkan adanya peningkatan prestasi pada siklusnya, yaitu pada siklus I hasil observasi aktivitas guru diperoleh dengan jumlah 56 dengan persentase $78 \%$ dengan kriteria baik, pada siklus II meningkat menjadi 58 dengan persentase $85 \%$ dengan kriteria sangat baik. Sedangkan untuk aktivitas siswa juga mengalami peningkatan. Hal ini dapat dilihat dari peningkatan skor pada tiap siklus, pada siklus I diperoleh skor 47 dengan nilai 65 dengan kriteria cukup, dan pada siklus II meningkat dengan perolehan skor 57 dengan nilai 84 dengan kriteria baik.

(2) Penerapan model pembelajaran Explicit Intruction dapat meningkatkan hasil belajar siswa pada tema Udara Bersih Bagi Kesehatan. Hal ini dibuktikan dengan adanya peningkatan persentase ketuntasan klasikal hasil belajar siswa yang minimal indikator keberhasilannya mencapai $75 \%$ dan rata-rata hasil belajar siswa yang diperoleh pada setiap siklus. Pada pretest diperoleh ketuntasan klasikal sebesar $27 \%$ dengan ratarata nilai siswa 56. Pada post-test siklus I ketuntasan belajar secara klasikal meningkat menjadi $64 \%$ dengan rata-rata nilai siswa 70 dan persentase ketuntasan hasil belajar siswa secara klasikal meningkat juga pada posttest siklus II menjadi $82 \%$ dengan rata-rata nilai siswa 81 . 
2197 Penerapan Model Pembelajaran Explicit Instruction untuk Meningkatkan Hasil Belajar Siswa Sekolah Dasar - Suratih Melianni Sibagariang, Asnita Hasibuan, Patri Janson Silaban

DOI: https://doi.org/10.31004/basicedu.v5i4.586

Hasil yang diperoleh dari penelitian ini menunjukkan adanya peningkatan hasil belajar siswa dengan menggunakan model pembelajaran Explicit Intruction pada Tema Udara Bersih Bagi Kesehatan, Subtema 3 Memelihara Kesehatan Organ Pernapasan Manusia, Pembelajaran 2 dan 5 di kelas V SD Negeri 106144 Sei Mencirim. Hal ini memberikan penjelasan bahwa penggunaan model pembelajaran merupakan salah satu faktor yang menjadi perhatian untuk meningkatkan hasil belajar siswa. Hal ini dilihat dari hasil belajar siswa melalui penggunaan model pembelajaran yang tepat dapat meningkatkan hasil belajar siswa dalam proses pembelajaran, yang pada nantinya memperoleh keberhasilan dan ketercapaian tujuan pembelajaran.

Dengan demikian, apabila model pembelajaran yang diterapkan kurang tepat pada materi pembelajaran maka akan berakibat buruk dalam proses pembelajaran. Oleh karena itu implikasi hasil penelitian ini bagi pendidikan adalah sebagai berikut: (1) Bagi siswa, menggunakan model pembelajaran Explicit Intruction membawa dampak positif terhadap hasil belajar siswa yakni telah terjadi peningkatan pada hasil belajar siswa. (2) Bagi guru, menggunakan model pembelajaran model pembelajaran Explicit Intruction pada Udara Bersih Bagi Kesehatan dapat digunakan guru sebagai acuan dalam meningkatkan hasil belajar siswa.

\section{DAFTAR PUSTAKA}

Abdul Rouf Dan Lufita Raghda. (2018). Peranan Guru Dalam Implementasi Kurikulum 2013 Di Madrasah Ibtidaiyah Negeri 1 Jombang. Sumbula, 903-926.

Ahmad, S. (2014). Problematika Kurikulum 2013 Dan Kepemimpinan Intruksional Kepala Sekolah. Jurnal Pencerahan, 98.

Akbar, D. (2017). Implementasi Pembelajaran Tematik Di Sekolah Dasar. Bandung: PT Remaja Rosdakarya.

Al-Tabany. (2015). Desain Pengembangan Pembelajaran Tematik. Jakarta: Prenada Media Group.

Anderson, \& Krthwohl. (2010). Desain Pengembangan Pembelajaran Tematik. Yogyakarta: Prenada Media Group.

Ariani, N. F., S'dijah, C., Dan Subandi. (2016). Penerapan Model Pembelajaran Inquiry Terbimbing Pada Materi Pecahan Sederhana Kelas III SD Prosiding Seminar Nasional Pendidikan Dasar 2016 Peningkatan Kualitas Pendidikan Dasar Dalam Menghadapi Daya Saing Regional (ASEAN). 608615.

Arikunto, Suhardjono, \& Supardi. (2017). Penelitian Tindakan Kelas. Jakarta: PT Bumi Aksara.

Aqib, Z., \& Dkk. (2016). Penelitian Tindakan Kelas Untuk Guru SD, SLB, Dan TK. Bandung: Yrama Widya.

Bahrudin Ardi, A. M. (2013). Penerapan Metode Inkuiri Untuk Meningkatkan Kualitas Pembelajaran IPA Pada Siswa Kelas V SDN 5 Mayonglor Kabupaten Jepara. Universitas Negeri Semarang: Doctoral Dissertation. Dalyono. (2012). Psikologi Pendidikan. Jakarta: Rineka Cipta.

Huda, M. (2014). Model-Model Pengajaran Dan Pembelajaran. Yogyakarta: Multi Pessido.

Istarani. (2017). 58 Model Pembelajaran Inovatif. Medan: CV Iscom Medan.

Jihad, Asep, \& Harris, A. (2018). Evaluasi Pembelajaran. Yogyakarta: Multi Pessido.

Joyce, B. C. (2009). Model Of Teaching (Terjemahan). Yogyakarta: Pustaka Pelajar.

Joyce, B., Calhoun, E., \& Weil, M. (2009). Model Of Teaching (Terjemahan). Yogyakarta: Pustaka Pelajar.

Kemendikbud. (2014). Permendikbud No. 103 Tentang Pedoman Pelaksanaan Pembelajaran. Jakarta: Kemendikbud.

Kristian, Y., \& Chaerul, M. (2010). Analisis Awal Implementasi Tempat Pengolahan Sampah Terpadu.

Lufita, A. R. (2018). Peranan Guru Dalam Implementasi Kurikulum 2013 Di Madrasah Ibtidaiyah Negeri 1 Jombang. Sumbula, 903-926. 
2198 Penerapan Model Pembelajaran Explicit Instruction untuk Meningkatkan Hasil Belajar Siswa Sekolah Dasar - Suratih Melianni Sibagariang, Asnita Hasibuan, Patri Janson Silaban

DOI: https://doi.org/10.31004/basicedu.v5i4.586

Madjid, A. (2014). Pembelajaran Tematik Terpadu. Bandung: Remaja Rosdakarya.

Meinita, M. D. N., Marhaeni, B., Winanto, T., Jeong, G. T., Khan, M. N. A., \& Hong, Y. K. (2013). Comparison Of Agarophytes (Gelidium, Gracilaria, And Gracilariopsis) As Potential Resources For Bioethanol Production. Journal Of Applied Phycology, 25(6), 1957-1961.

Mulyasa. (2008). Implementasi Kurikulum Tingkat Satuan Pendidikan. Bandung: PT Bumi Aksara.

Mulyasa, E. (2013). Pengembangan Dan Implementasi Kurikulum 2013. Bandung: PT Remaja Rosdakarya.

Nurjanah, N. (2016). Peningkatan Hasil Belajar IPA Dengan Menerapkan Metode Inkuiri Siswa Kelas V SD Negeri 68 Kec. Bacukiki Kota Parepare. Publikasi Pendidikan, 107-110.

Purwanto. (2017). Evaluasi Hasil Belajar. Yogyakarta: Pustaka Belajar.

Ruslamiarti, F. R. (2013). . Hubungan Gaya Belajar Dengan Hasil Belajar Bahasa Indonesia Siswa Kelas 5 SDN 17 Kota Bengkulu, 30.

Shoimin. (2016). 68 Model Pembelajaran Inovatif Dalam Kurikulum 2013. Yogyakarta: Ar-Ruzz Media.

Slameto. (2017). Belajar Dan Faktor-Faktor Yang Mempengaruhi. Jakarta: Rineka Cipta.

Sanjaya. (2010). Strategi Pembelajaran Berorientasi Standar Proses Pendidikan. Jakarta: Kencana Prenada Media Group.

Sudjana, N. (2018). Penilaian Hasil Proses Belajar Mengajar. Bandung: PT Remaja Rosdakarya.

Sumiati, \& Asra. (2018). Metode Pembelajaran. Bandung: CV Wacana Prima.

Susanto, A. (2013). Teori Belajar Dan Pembelajaran Di Sekolah Dasar. Jakarta: Prenada Media Group.

Trianto. (2012). Mendesain Model Pembelajaran-Inovatif-Progresif. Jakarta: Kencana Prenada Media Group.

Undang-Undang Republik Indonesia No. 20 Tahun 2003 Tentang Sistem Pendidikan Nasional. (N.D.). Jakarta: Departemen Pendidikan Nasional Republik Indonesia.

Widyastuti, F. P. (2018). Peningkatan Hasil Belajar Siswa Kelas 4 SD Melalui Model Pembelajaran Inquiry Learning. Jurnal Kiprah, 1-13. 